\title{
Leucine: a key amino acid in ageing-associated sarcopenia?
}

\author{
Dominique Dardevet*, Isabelle Rieu, Pierre Fafournoux, Claire Sornet, Lydie Combaret, Alain Bruhat, \\ Sylvie Mordier, Laurent Mosoni and Jean Grizard \\ Unité de Nutrition et Métabolisme Protéique, Institut National de la Recherche Agronomique, \\ Theix, 63122 Saint-Genès-Champanelle, France
}

\begin{abstract}
During ageing, a progressive loss of muscle mass has been well described in both man and rodents. This loss of proteins results from an imbalance between protein synthesis and degradation rates. Although some authors have shown a decrease of myofibrillar protein synthesis rates in human volunteers, this imbalance is not clearly apparent when basal rates of protein turnover are measured. A decrease in muscle protein synthesis stimulation was detected nevertheless in ageing rats during the postprandial period, suggesting that the 'meal signal' was altered during ageing. Many results now suggest that aged muscle is less sensitive to the stimulatory effect of amino acids at physiological concentrations but is still able to respond if the increase in aminoacidaemia is sufficiently large. Indeed amino acids play an important role in regulating muscle protein turnover both in vitro and in vivo. At the molecular level, amino acids modulate gene expression. Amino acid response elements have been characterised in the promoter of transcriptional factor CCAAT-enhancer binding protein homologous protein and asparagine synthetase genes. Among amino acids, leucine seems to play the major role in regulating the metabolic function. It inhibits proteolysis and stimulates muscle protein synthesis independently of insulin. Leucine has been shown to act as a real mediator by modulating specifically the activities of intracellular kinases linked to the translation of proteins such as phosphatidylinosinol 3' kinase and mammalian target of rapamycin-70 $\mathrm{kDa}$ ribosomal protein $\mathrm{S} 6\left(\mathrm{p} 70^{\mathrm{S} 6 \mathrm{~K}}\right)$ kinases. We recently demonstrated in vitro that protein synthesis of ageing rat muscles becomes resistant to the stimulatory effect of leucine in its physiological concentration range. However, when leucine concentration was increased greatly above its postprandial level, protein synthesis was stimulated normally. Moreover, we studied the effect of meal leucine supplementation on in vivo protein synthesis in adult and ageing rats. Leucine supplementation had no additional effect on muscle protein synthesis in adults but totally restored its stimulation in ageing rats. Whether chronic oral leucine supplementation would be beneficial for maintaining muscle protein mass in elderly men and women remains to be studied.
\end{abstract}

\section{Ageing: Leucine: Amino acids: Sarcopenia}

\section{Introduction}

Normal ageing is characterised by a decline in skeletal muscle mass and strength associated with increased muscle fatigability. This phenomenon, named sarcopenia, reduces physical activities and generates a general weakness in elderly men and women (Evans et al. 1995). The weakness of quadriceps muscle predisposes to impaired locomotion, frequent falls and increases the risk of hip fractures in the elderly. In addition, there is an increased susceptibility to illness since skeletal muscles are the major reservoir of body proteins, and consequently of amino acids, which could be used for energy production or the synthesis of acute-phase proteins by the liver. Due to the reduced muscle mass, the ability of aged individuals to fight and recover from stress is impaired and this impairment promotes the decrease of muscle mass generated by the stress itself. All these factors taken together, sarcopenia reduces the quality

\footnotetext{
Abbreviations: AARE, amino acid response elements; AS, asparagine synthetase; BCAA, branched-chain amino acids; C/EBP, CCAATenhancer binding protein; CHOP, CCAAT-enhancer binding protein homologous protein; mTOR, mammalian target of rapamycin; $\mathrm{p} 70^{\mathrm{S} 6 \mathrm{~K}}, 70 \mathrm{kDa}$ ribosomal protein $\mathrm{S} 6$.

* Corresponding author: Dr Dominique Dardevet, fax +33 4736247 55, email Dominique.Dardevet@clermont.inra.fr
} 
of life for the rapidly expanding older population in the Western countries. Elucidating the mechanisms that result in muscle wasting in ageing is therefore of obvious importance. It is estimated that 20-30 billion dollars of health costs in the United States of America are spent on problems directly related to sarcopenia (Schneider \& Guralnik, 1990).

The decrease of lean mass is associated with an increase in the total amount of lipid stores (Cohn et al. 1980) (Fig. 1).

This increase in lipid stores appears during the third decade in men but is delayed in women (Forbes \& Reina, 1970). The accumulation of visceral and total body fat is thought to be a consequence of the reduced daily energy expenditure, and represents a risk factor for the development of type II diabetes during ageing (Holloszy et al. 1985, 1991). In rodent models, although the whole-body protein mass is not reduced, wasting is nevertheless obvious in white muscles, which are mainly constituted of type II (glycolytic) fibres (Holloszy et al. 1991). Muscle wasting results from a reduction of fibre areas, a loss of myofibrillar proteins and conversion of type II into type I (oxidative) fibres (Carlson, 1992). Alterations in mechanical and biochemical properties of skeletal muscle are very similar in elderly men and women, and elderly rodents (Taylor et al. 1992). Proteins undergo a continuous process of degradation and synthesis. Thus, protein storage in skeletal muscle results directly from the overall balance between the rates of protein synthesis and breakdown. Sarcopenia observed during ageing is then the consequence of a decreased protein synthesis, increased proteolysis or a combination of the two phenomena. The present review focuses on alterations of muscle protein metabolism during ageing in the postabsorptive state and will examine the response of both muscle protein synthesis and proteolysis to amino acids, which are thought to be one of the major regulators of muscle protein metabolism in the postprandial state.

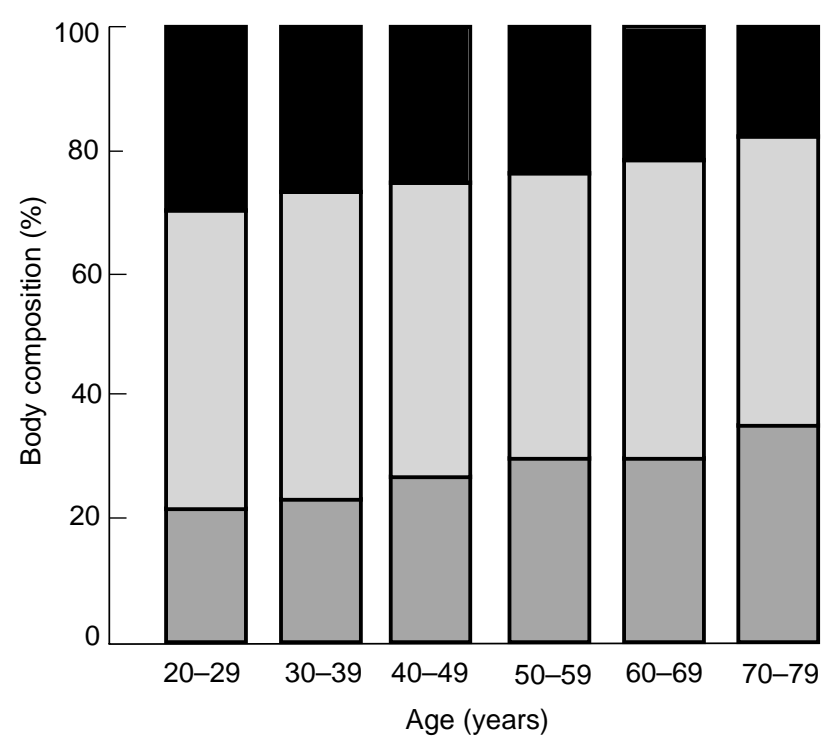

Fig. 1. Body composition in man as a function of age. $\mathbf{\square}$, Muscle; , other tissues; $\square$, fat. (Adapted from Cohn et al. 1980.)

\section{Ageing and post-absorptive muscle protein metabolism}

Young et al. (1975) were the first to report a decline in whole-body protein synthesis from birth to old age. However, this decrease is more pronounced in the early stage of life (1 month to 20 years old) than between adult and old ages. Since then, various studies confirmed this observation and it became obvious that whole-body protein synthesis is either normal or increased in the elderly when expressed per $\mathrm{kg}$ of fat-free mass (Millward et al. 1997). Despite the fact that skeletal muscle represents $45 \%$ of body weight, its contribution to whole protein synthesis is small (<30\%) (Nair et al. 1988). Thus, slight changes in muscle protein synthesis could not be detected when whole protein synthesis was assessed. Nair et al. (1995) estimated that a $70 \mathrm{~kg}$ patient who has muscle wasting of $30 \%$ muscle mass will decrease his whole-body protein synthesis by only approximately $8 \%$. In order to determine whether alteration of muscle protein synthesis occurs during ageing, it is necessary to measure directly muscle protein synthesis rates. During the last few years, several laboratories have studied the intensity of muscle protein synthesis during ageing in order to explain the protein wasting observed. Although it is now well established that in vivo protein synthesis in skeletal muscles decreases from growing to mature mammals (Millward et al. 1975; Waterlow et al. 1978; Lewis et al. 1984; Attaix et al. 1988), it is less obvious between mature and elderly organisms. In very recent studies with healthy volunteers, Volpi et al. (1999, 2000) showed by using phenylalanine kinetics across the leg that muscle protein synthesis was not modified during ageing and was similar between 30- and 71-year-old individuals. Previously, Yarasheski et al. $(1992,1995)$ recorded the same conclusion but the same group also showed (Yarasheski et al. 1993) a decrease in muscle protein synthesis between young and ageing volunteers during the post-absorptive state. The synthesis of muscle proteins results from the respective synthesis of the different types of proteins found within the muscle cells, i.e. myofibrillar, sarcoplasmic and mitochondrial. The effect of ageing on the synthesis of these different protein fractions has been investigated since they reportedly have different synthesis rates. Welle et al. (1993) found there was a $28 \%$ decrease in myofibrillar protein synthesis rates in the elderly but not of sarcoplasmic proteins. A more recent study (Rooyackers et al. 1996; Balagopal et al. 1997) conducted in young, middle-aged and ageing subjects showed that sarcoplasmic protein synthesis was also unchanged during ageing whereas myofibrillar and mitochondrial protein synthesis rates were reduced by 31 and $40 \%$ respectively in middleaged subjects. By contrast, with advancing age (middleaged $v$. ageing subjects), rates of myofibrillar protein synthesis only slightly decreased and no further reduction of the synthesis of mitochondrial proteins was observed. Taken together, it is difficult to correlate these observations with muscle wasting observed during ageing. Indeed, the major decrease of muscle protein synthesis (myofibrillar and mitochondrial) occurred in middle-aged subjects who presented a non-significant reduction of their total muscle mass (Balagopal et al. 1997). On the other hand, in ageing subjects who showed a significant decrease of muscle mass 
$(-36 \%)$, myofibrillar, sarcoplasmic and mitochondrial protein synthesis rates were not significantly reduced when compared with those measured in middle-aged subjects (Balagopal et al. 1997). In rodent studies, the effect of ageing on muscle protein synthesis is no clearer. For example, the same group reported a decrease (Lewis et al. 1984) or an increase of muscle protein synthesis (El Haj et al. 1986) in the rat tibialis anterior between 1 and 2 years of age. In rat gastrocnemius muscle, Kelly et al. (1984) showed a decreased protein synthesis while Mays et al. (1991), Mosoni et al. (1993) and Dardevet et al. (1994, 2002) reported non-modification or even an increased muscle protein synthesis. Therefore, age-related alterations in protein synthesis in the basal state may contribute to, but cannot explain, the slow erosion of muscle protein mass in either human or rodent models.

Since muscle protein mass is also directly dependent on protein degradation, a higher rate of proteolysis might be expected in ageing organisms to explain the protein loss in muscles that maintained the same protein synthesis rates at both ages. Only a few reports regarding variation of muscle protein degradation during ageing are available. When assessed from 3-methylhistidine urinary excretion (an indirect index of myofibrillar protein degradation), Young \& Munro (1978) showed that 3-methylhistidine excretion was similar in adult and ageing subjects when expressed per $\mathrm{g}$ of creatinine (which is an index of muscle mass). Mosoni $e t$ al. (1999) also found no modification of 3-methylhistidine urinary excretion between 1- and 2-year-old rats. When more direct methods were used to assess muscle protein degradation (i.e. phenylalanine fluxes across the leg), Volpi et al. (1999) and Volpi \& Rasmussen (2000) were also unable to find a modification of muscle proteolysis between 30- and 71-year-old volunteers. Such a similarity also appears when measuring gene expression for several proteins involved in the three major proteolytic pathways in rat muscles (cathepsin D, m-calpain, ubiquitin) (Mosoni et al. 1999).

So it appears that in the basal post-absorptive state, muscle protein degradation is not increased in ageing organisms and that muscle protein synthesis is not or only very slightly altered. So far, what was observed in the basal post-absorptive state could not explain the muscle atrophy observed during ageing. Since there is a diurnal cycle of protein metabolism with catabolic, post-absorptive and anabolic, postprandial periods (Millward et al. 1994), it can be postulated that age modifies muscle protein metabolism by affecting the mechanisms involved in the control of protein turnover in the postprandial state.

\section{Ageing and postprandial muscle protein metabolism}

During the day, protein metabolism is modified by food intake. Whole-body proteins are stocked during the postprandial periods and lost in post-absorptive periods. With a muscle protein mass that remains constant, the loss of muscle proteins is compensated by the same protein gain at the postprandial state (Fig. 2).

In adult volunteers, oral feeding is associated with an increase of whole-body protein synthesis and decrease of proteolysis (Rennie et al. 1982; Pacy et al. 1994; Boirie et

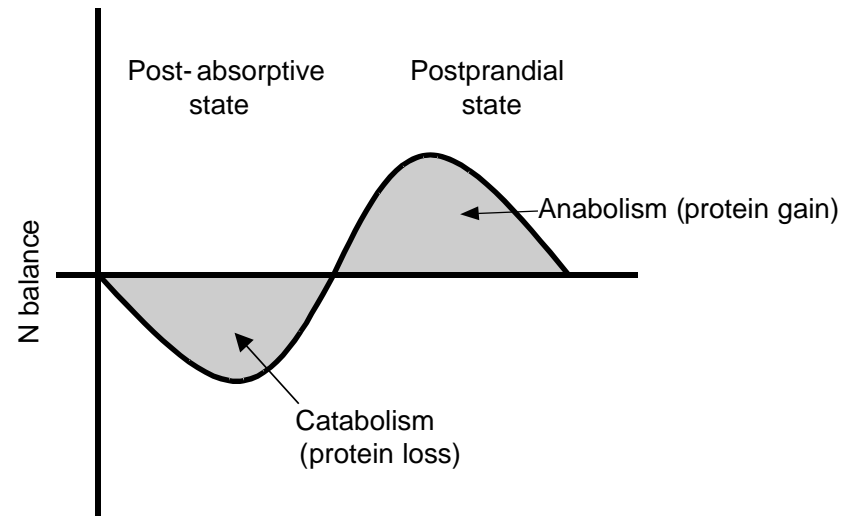

Fig. 2. Theoretical changes in nitrogen balance during the postabsorptive and postprandial states.

al. 1996; Volpi et al. 1996; Arnal et al. 2000). These changes are mediated by feeding-induced increases in plasma concentrations of both nutrients and hormones. Many studies suggest that amino acids and insulin play major roles in promoting postprandial protein anabolism. Feeding a protein-free diet to human subjects (Volpi et al. 1996) or rodents (Yoshizawa et al. 1997a, 1998) did not induce any stimulation of protein synthesis despite a significant rise in plasma insulin, suggesting that amino acids but not insulin are essential in postprandial stimulation of protein synthesis. In accordance with this lack of an effect of insulin, refeeding causes the same effects on protein synthesis in diabetic mice and control animals despite no changes in postprandial plasma insulin concentrations (Svanberg et al. 1996, 1997). Likewise, provision of exogenous insulin to freely fed rodents did not increase muscle protein synthesis beyond the effect of refeeding (Garlick et al. 1983; Svanberg et al. 1996). Furthermore, the effect of feeding on protein metabolism is correlated to the amount of protein intake. Pacy et al. (1994) showed whole-body protein synthesis was more stimulated and protein degradation was more inhibited when the protein content of the diet was increased from 0.36 to $2.77 \mathrm{~g} / \mathrm{kg}$ per d.

Studies have shown specific differences between adult and elderly subjects in the response of protein metabolism during the transition from post-absorptive to the fed state. At the whole-body level, proteolysis inhibition in the fed state was lower in ageing men or women than in adults (Boirie et al. 1996; Arnal et al. 2000). The stimulatory effect of food intake has also been investigated in skeletal muscle protein synthesis. Welle et al. (1994) showed no difference in whole-body incorporation of leucine into proteins in the young. However, the fractional myofibrillar protein synthesis in the vastus lateralis muscle was $28 \%$ slower in the older group. In rats, Mosoni et al. (1995) and Dardevet et al. (2002) found that protein synthesis was stimulated only in adult but not in elderly rats. This loss of protein synthesis response to the anabolic effect of food intake could be involved in muscle protein loss that occurs during ageing; since, every day, lost protein during the post-absorptive period will not be completely recovered during the postprandial period in the oldest subjects. 
Since amino acids play an important role in regulating protein synthesis, it has been hypothesised that during ageing, availability of amino acids could be affected. Boirie et al. (1997) have shown in human volunteers that the firstpass splanchnic uptake of leucine increases with age and may limit the availability of amino acids to the peripheral tissues. Volpi et al. (1999) confirmed this observation but showed that the delivery of amino acids to the tissues increased to the same extent in both adult and elderly individuals. In rats (Dardevet et al. 2002), no difference in DM intake or in essential amino acid concentrations in plasma was recorded, thus a defect of amino acid availability cannot be responsible per se for the defect of postprandial anabolism. Other studies have explored the direct effect of amino acids on muscle protein synthesis and have shown that protein synthesis responds normally if amino acids are infused continuously in elderly rats (Mosoni et al. 1993). Similarly, Volpi et al. (1999) observed that muscle protein synthesis was still stimulated with an increase of amino acid availability in elderly human subjects after oral amino acid administration. It is important to note that the amount of amino acids infused or orally given in these two experiments led to a sustained large hyperaminoacidaemia (most of the essential amino acids were more than doubled) and was not representative of the plasma amino acid profile observed with a normal mixed meal consumption (Elia et al. 1989; Bergström et al. 1990). Recently, Arnal et al. (1999) demonstrated that the response of protein turnover was restored in elderly subjects if a 'protein-pulse feeding' pattern ( $80 \%$ of daily proteins in one meal) was used instead of 'spread-protein feeding' (daily proteins equally distributed). Even if the plasma amino acids were not measured in this experiment, it could be easily assumed that amino acid availability to peripheral tissues was higher with protein-pulse feeding than with protein-spread feeding. These results suggest that aged muscle is less sensitive to the stimulatory effect that amino acids have at physiological concentrations but is still able to respond if the increase in aminoacidaemia is sufficiently large.

\section{Leucine and postprandial anabolism}

\section{Regulation of muscle protein synthesis}

Several studies have indicated that branched-chain amino acids (BCAA) regulate skeletal muscle protein synthesis. In vitro as well as in vivo, addition or infusion of BCAA at 5 times fasting plasma concentrations enhanced muscle protein synthesis (Fulks et al. 1975; Li \& Jefferson, 1978). Furthermore, Garlick \& Grant (1988) showed that infusion of BCAA and glucose stimulates skeletal muscle protein synthesis in post-absorptive rats as efficiently as a complete amino acid mixture and glucose. These data suggest that BCAA are responsible for the anabolic effect of amino acids on muscle protein synthesis. Buse et al. (1975) demonstrated in vitro in rat hemidiaphragms that leucine stimulated protein synthesis as effectively as a mixture of all three BCAA, suggesting that the effect of amino acids on muscle protein synthesis can be attributable to leucine alone and independently of the other BCAA. Li \& Jefferson (1978) confirmed this hypothesis on hindlimb preparations, in which leucine at 10 times fasting plasma concentrations reproduced the effect of all BCAA on muscle protein synthesis. More recently, Anthony et al. (2000a) showed that orally administered leucine stimulated muscle protein synthesis by itself in vivo and this was independent of insulin. However, several authors were unable to detect an effect of leucine alone on muscle protein synthesis in post-absorptive rats or ruminants (McNurlan et al. 1982; Funabiki et al. 1992; Papet et al. 1992). The discrepancy between in vitro and in vivo studies remains unclear. Despite differences in study design and animal species, recent work of our laboratory (Dardevet et al. 2000) may explain these apparent conflicting results. In our study on epitrochlearis muscle, leucine increased protein synthesis in vitro and this stimulation occurred at physiological concentrations (100-200 $\mu \mathrm{M})$ (Fig. 3). In addition, maximal stimulation was obtained where leucine concentrations ranged between the post-absorptive and postprandial levels. In vitro, since muscles are incubated under the normal post-absorptive leucine concentrations (incubation medium without leucine), the stimulation of protein synthesis can be recorded. On the other hand, in vivo, the presence of plasma leucine, which is already at the post-absorptive levels and thus close to the maximum effect of leucine on muscle protein synthesis, can prevent a significant further increase of muscle protein synthesis.

\section{Regulation of muscle protein degradation}

BCAA have also been shown to inhibit protein breakdown in skeletal muscle studied both in vitro and in vivo. The three BCAA appeared responsible for the inhibition of protein degradation by plasma amino acids in rat diaphragm (Fulks et al. 1975). Louard et al. (1990) indicated that BCAA infusion suppresses the rate of phenylalanine appearance in the systemic circulation in normal man, and specifically its release from forearm muscle. This implies a suppression of whole-body and forearm muscle proteolysis in response to BCAA. In addition, elevated BCAA and

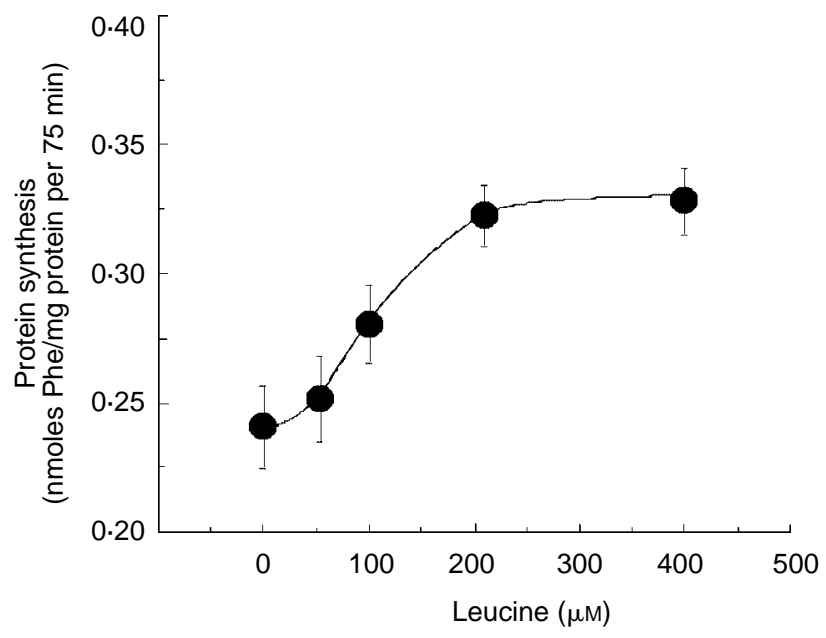

Fig. 3. Effect of increasing leucine concentration on epitrochlearis muscle protein synthesis in vitro in young rats. Phe, phenylalanine. Mean values are shown with vertical bars representing standard errors. (Adapted from Dardevet et al. 2000.) 
other amino acids were required to restore tissue sensitivity and specificity to the effects of insulin on protein metabolism after $4 \mathrm{~d}$ of fasting in healthy volunteers (Frexes-Steed et al. 1990), and more recently variation in the sensitivity of the insulin-mediated inhibition of proteolysis to amino acid supply has been shown to be an important determinant of the overall efficiency of postprandial protein utilisation (Fereday et al. 1998). Buse et al. (1975) and Fulks et al. (1975) showed that leucine alone, at physiological concentrations, was able to inhibit protein breakdown in rat diaphragm. In accordance with these observations, leucine infusion decreases protein degradation in human subjects (Nair et al. 1992). Moreover, in mouse C2C12 myotubes, leucine starvation accounts for $30-40 \%$ of the maximal acceleration of protein breakdown obtained with total amino acids withdrawal (Mordier et al. 2000). These authors also indicated that leucine starvation induces autophagy and as a consequence an increase in lysosomaldependent proteolysis. Busquets et al. (2000) confirmed this observation on incubated extensor digitorum longus muscle using supraphysiological leucine concentrations (10 $\mathrm{mM}$ ) in the medium. They showed that the effect of BCAA on muscle proteolysis is mediated in the short term by the inhibition of lysosomal proteolysis and, in a longer period, by regulation of ubiquitin-proteasome-dependent proteolysis based on the inhibition of gene transcription observed.

\section{Leucine: an active bio-substrate}

Since leucine is able to reproduce the effect of all amino acids on muscle protein synthesis, it has been hypothesised that this effect was not dependent on the amino acid concentration itself but on a specific signal initiated by leucine. The stimulation of skeletal muscle protein synthesis caused by feeding a complete diet has been shown to be mediated by an increase in the initiation of mRNA translation (Millward et al. 1983; Kelly \& Jefferson, 1985; Preedy \& Garlick, 1986; Yoshizawa et al. 1995). One of the most tightly regulated steps in translation initiation is the binding of mRNA to the 40S subunit (Pain, 1996; Rhoads, 1999; Shah et al. 2000). This step involves the binding of eIF4E to the $\mathrm{m}^{7}$ GTP cap at the $5^{\prime}$ end of the mRNA and the subsequent binding of the eIF4E-mRNA complex to eIF4G, which is a critical step in the formation of the 48S pre-initiation complex. Two major mechanisms have been described that contribute to the regulation of the assembly of these complexes, each of which involves reversible phosphorylation of proteins implicated in the process. Previous studies in vitro have reported that increased phosphorylation of eIF4E is observed in cultures of cells in response to a variety of stimuli (for example, growth factors, hormones) and is positively correlated with changes in protein synthesis (Rhoads et al. 1993). However, in vivo studies do not support these results. Indeed, the phosphorylation state of eIF4E was not changed in diabetic or insulintreated diabetic rats (Kimball et al. 1996); it also was not changed in skeletal muscle of overnight fasted or refed animals (Yoshizawa et al. 1997a). Another mechanism through which translation initiation can be regulated involves phosphorylation of the eIF4E binding protein 4E$\mathrm{BP} 1$. Indeed, eIF4E bound to 4E-BP1 can bind to the $\mathrm{m}^{7}$
GTP cap structure, but cannot bind to eIF4G, the active complex to stimulate translation initiation (for a review, see Anthony et al. 2001). Thus, 4E-BP1 competes with eIF4G for association to eIF4E. The ability of 4E-BP1 to bind to eIF4E is largely dependent on the phosphorylation state of 4E-BP1. Phosphorylation of 4E-BP1 releases eIF4E from the 4E-BP1-eIF4E complex, which in turn is available to bind to eIF4G (Fig. 4).

Recent investigations have been undertaken to study the effect of leucine on these intracellular processes. Anthony et al. (2000a) showed that orally administered leucine alone stimulated muscle protein synthesis and that this stimulation is correlated with a hyperphosphorylation of 4E-BP1. The formation of the complex 4E-BP1-eIF4E is thus inhibited and the complex eIF4E-eIF4G is increased. Leucine has also been shown to increase the phosphorylation of $70 \mathrm{kDa}$ ribosomal protein S6 (p70S6K) and consequently its activation (Anthony et al. 2000b; Dardevet et al. 2000). p70S6K activation has been shown to regulate the translation of specific mRNA by modulating phosphorylation of ribosomal protein S6. The activation of p70S6K and 4E-BP1 by amino acid or leucine involves an upstream signalling pathway including the mammalian target of rapamycin (mTOR) (Patti et al. 1998; Kimball et al. 1999). In vitro, stimulation

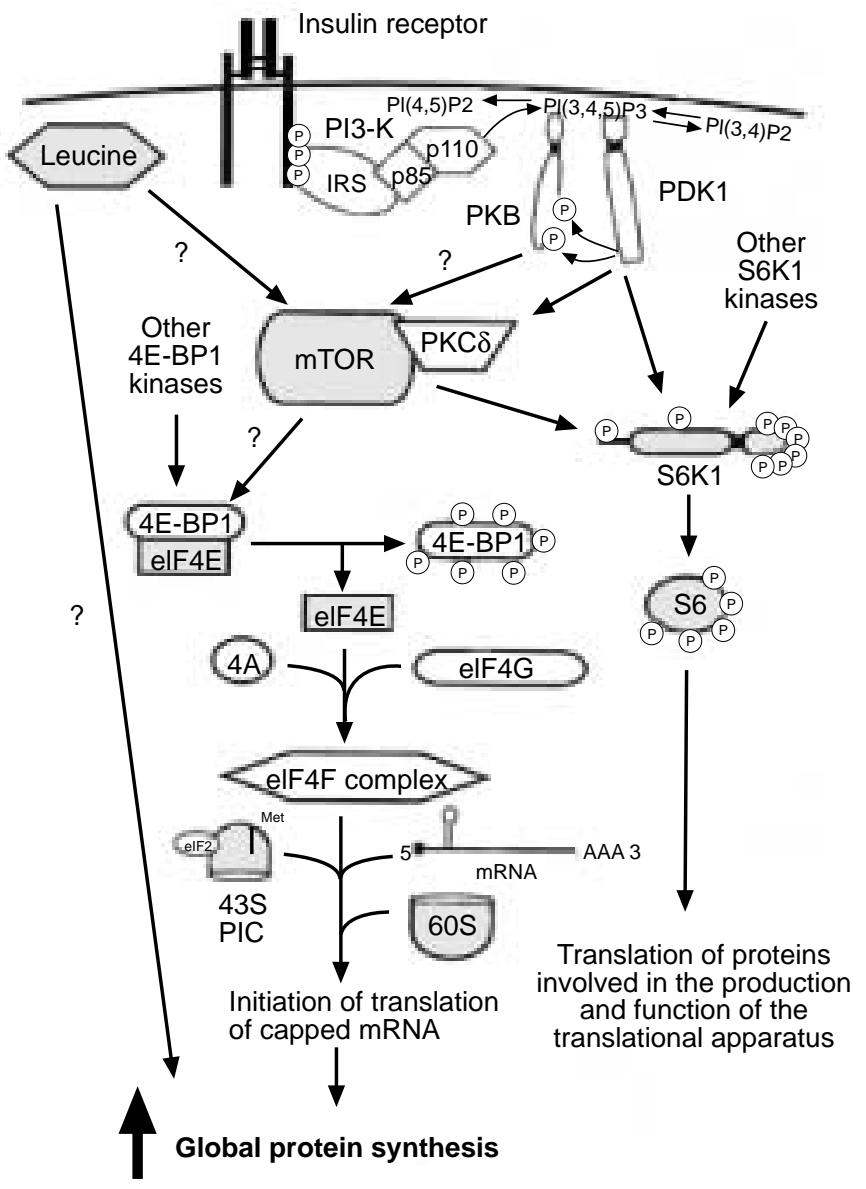

Fig. 4. Possible mechanisms of action of leucine on muscle protein synthesis. IRS, insulin receptor substrate; PKB, protein kinase B; PDK, phosphoinositide-dependent protein kinase; mTOR, mammalian target of rapamycin; PKC, protein kinase C; Met, methionine. (Adapted from Anthony et al. 2001.) 
of muscle protein synthesis by leucine is totally inhibited by rapamycin, a specific inhibitor of mTOR (Dardevet et al. 2000). In vivo, when intravenously injected, rapamycin completely prevents leucine-dependent stimulation of muscle protein synthesis in vivo in association with a lack of hyperphosphorylation of $\mathrm{p} 70^{\mathrm{S} 6 \mathrm{~K}}$ and 4E-BP1. Taken together, these results suggest that leucine stimulates mTOR activity in skeletal muscle for initiating protein synthesis and could be considered as a real active bio-substrate.

In addition to modulating activities of specific intracellular kinases and factors involved directly in the initiation of protein translation, leucine also has been shown to modulate the transcription of selected genes.

\section{Transcriptional activation of mammalian genes by amino acid starvation}

At the molecular level, most results have been obtained by studying the up-regulation of asparagine synthetase (AS) and CCAAT-enhancer binding protein (C/EBP) homologous protein (CHOP) gene expression by amino acid availability. By first identifying the genomic cis-elements and then the corresponding transcription proteins responsible for regulation of these specific target genes, it is anticipated that one can progress backwards up the signal transduction pathway to understand the individual steps required.

Amino acid response elements (AARE) have been characterised in the promoter of CHOP and AS genes (Bruhat et al. 1997, 2000; Barbosa-Tessmann et al. 1999, 2000). These two AARE show some homology with specific binding sites of the C/EBP and ATF/CREB transcription factors. Although it appears that CHOP and AS AARE sequences reveal some similarity, there are several lines of evidence suggesting that induction of $\mathrm{CHOP}$ and $\mathrm{AS}$ following amino acid starvation does not occur through a unique and common mechanism. Particularly, the cis-acting elements required for induction of the $\mathrm{CHOP}$ gene following amino acid starvation (AARE) or unfolded protein response pathway are located in different sequences, whereas a unique sequence is required for AS induction following either amino acid limitation or activation of the unfolded protein response pathway. In addition the transcription factors involved in the amino acid-dependent regulation of CHOP and AS expression are different. For example, ATF2 plays a pivotal role in CHOP expression in response to leucine starvation but is not able to bind the AARE of the AS gene. On the other hand, C/EBP $b$ binds and regulates AS AARE whereas it is not involved in the regulation of $\mathrm{CHOP}$ expression by amino acid limitation (Barbosa-Tessmann et al. 2000).

The study of the proteins binding the AARE suggests that several signalling pathways are involved in the up regulation of gene expression by amino acid limitation. It has been suggested (Harding et al. 2000; Bruhat \& Fafournoux, 2001) that one of these pathways could be related to the general control process that exists in yeast (Hinnebusch, 1994) where the GCN2p plays a pivotal role. Indeed, this kinase controls not only the rate of translation initiation but also up regulates a coordinately expressed set of genes involved in amino acid biosynthesis and metabolism. Recently, the human homologue of GCN2 has been cloned and studied (Berlanga et al. 1999; Sood et al. 2000). GCN2p phosphorylates the initiation factor eIF2 $\alpha$ on the serine 51 that leads to inhibition of protein synthesis. Using embryonic stem cells with a targeted mutation in GCN2, Harding et al. (2000) demonstrated that GCN2p is required for the induction of CHOP mRNA in response to leucine starvation. GCN2p couples leucine limitation to eIF $2 \alpha$ phosphorylation and to activation of gene expression.

The mechanisms involved in the amino acid control of gene expression have just begun to be understood in mammalian cells. Defining the precise cascade of molecular events by which the cellular concentration of an individual amino acid regulates gene expression will be an important contribution to our understanding of metabolite control in mammalian cells.

\section{Stimulation of muscle protein metabolism by leucine and ageing}

We investigated whether or not a decrease in muscle protein synthesis sensitivity to leucine during ageing may explain the defect in postprandial anabolism (Dardevet et al. 2000). Our study clearly showed that muscle protein synthesis still responded to the leucine signal in ageing animals, but the half-maximum effect was observed at amino acid levels 2 to 3 times greater than in young or adult rats (Fig. 5). This indicated that, at postprandial leucine levels, muscle protein synthesis was maximally stimulated in adult rats whereas it was still poorly increased in ageing animals. Indeed, we have measured the plasma amino acid concentrations in ageing and adult rats in post-absorptive and postprandial states and no difference of aminoacidaemia was found.

The decreased sensitivity of muscle protein synthesis to leucine in aged rats suggests that the signalling pathway that carries the leucine signal to the protein translation machinery was less responsive to the amino acid than in

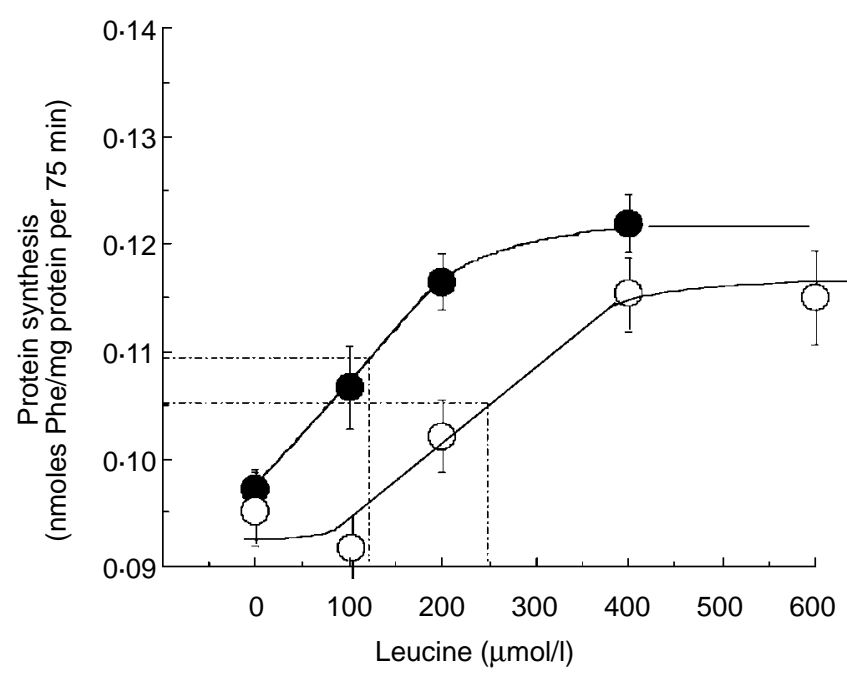

Fig. 5. Effect of increasing leucine concentrations on epitrochlearis muscle protein synthesis measured in vitro in adult and old rats. The half-maximum effect for adult rats $(\bullet)$ was $115 \mu \mathrm{mol} / \mathrm{l}$ and for old rats (O) was $250 \mu \mathrm{mol} / \mathrm{l}$. Mean values are shown with vertical bars representing standard errors. (Adapted from Dardevet et al. 2000.) 
adult rats. Our study (Dardevet et al. 2000) demonstrated that $\mathrm{p} 70^{\mathrm{S} 6 \mathrm{~K}}$ activity was stimulated by leucine in both adults and ageing animals but, as recorded with protein synthesis, this activation occurred with higher and supraphysiological levels of leucine (half-maximum effects of 110 v. $260 \mu \mathrm{mol} / \mathrm{l}$, respectively). Thus, to fully activate, postprandial leucine concentrations are sufficient in adult rats whereas up to $400 \mu \mathrm{mol} / \mathrm{l}$ are needed for ageing animals. Our results showed a straight correlation between sensitivity of muscle protein synthesis and sensitivity of $\mathrm{p} 70^{\mathrm{S} 6 \mathrm{~K}}$ activation to leucine. This confirms the fact that the signalling pathway $\mathrm{PI}_{3}{ }^{\prime}$ kinase-mTOR-p $70^{\mathrm{S} 6 \mathrm{~K}}$ is involved in the stimulation of muscle protein synthesis by leucine.

From this in vitro data, we hypothesised that the defect in postprandial stimulation of muscle protein synthesis could be overcome by increasing plasma leucine concentration in vivo. We studied the effect of acute meal leucine supplementation on protein synthesis in adult and ageing rats in both gastrocnemius and soleus muscles. In these in vivo experiments, leucine supplementation had no additional effect on muscle protein synthesis in adults but totally restored its stimulation in ageing rats and this occurred in both muscles studied (Fig. 6).

Only leucine concentrations in plasma reached supraphysiological levels in both age groups (twice the control postprandial values) and confirmed in vivo our hypothesis that ageing rat muscles are less sensitive to the leucine signal but are still able to respond when the concentration of this amino acid is sufficiently increased.

Leucine has been shown to stimulate insulin secretion, and the restoration of muscle protein synthesis in ageing rats could originate indirectly through an increase of plasma insulinaemia. This could not explain the results in our experiment (Dardevet et al. 2000) since the kinetics of insulinaemia were not significantly different in the rats fed the control and the leucine-supplemented meals.
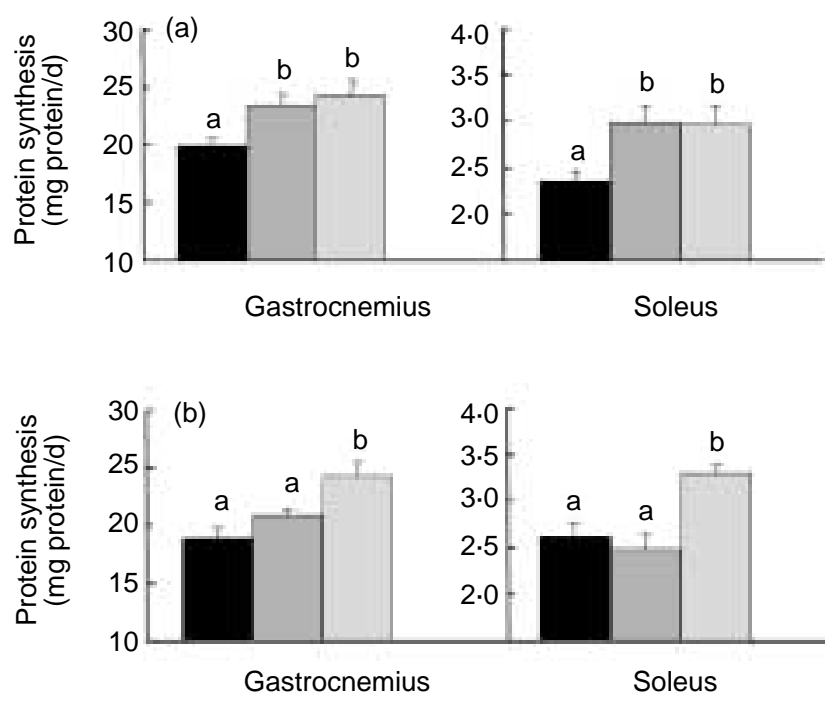

Fig. 6. Effect of leucine supplementation on muscle protein synthesis in adult (a) and old (b) rats that were food-deprived or refed for $1 \mathrm{~h}$ with a control alanine diet or a control diet supplemented with leucine. Values with different letters are significantly different $(P<0.05)$. (Adapted from Dardevet et al. 2002.)
Furthermore, insulin levels were not different from those of the adult groups in which a stimulation of muscle protein synthesis has been nevertheless recorded. However, it is important to emphasise that the presence of insulin seems nevertheless indispensable in the postprandial stimulation of muscle protein synthesis by amino acids. Indeed, the acute decrease of postprandial insulinaemia to post-absorptive levels due to either anti-insulin serum (Millward et al. 1983) or diazoxide treatment (Sinaud et al. 1999; Balage et al. 2001) greatly impaired muscle protein synthesis.

Our study (Mosoni et al. 1993) explains why amino acid infusion, which induced a three-fold increase in plasma leucine, stimulated muscle protein synthesis to the same extent in adult and ageing rats. A similar conclusion could be deduced from the study of Volpi et al. (1999) who observed a similar effect of oral amino acid administration on muscle protein synthesis in adult and elderly volunteers; leucine concentrations were 2.5 to 3.5 higher than with a control meal. Recently, Arnal et al. (1999) demonstrated that the response of protein turnover was restored in elderly subjects if a 'pulse-protein feeding' pattern (80\% of daily protein intake in one meal) was used instead of spread-protein feeding (daily proteins equally distributed in four meals). Even if the plasma amino acids were not measured in this experiment, it could be easily assumed that amino acid availability after the high-protein meal to peripheral tissues (i.e. leucine) was higher with pulse-protein feeding than with spread-protein feeding. An increase of dietary protein intake was thus beneficial for the maintenance of muscle protein synthesis in an elderly population. However, it required $80 \%$ instead of $30 \%$ of proteins in the meal and it has been shown that high-protein diets may have deleterious effects on renal function in the elderly (Rowe, 1980). Since in our experiment (Mosoni et al. 1993) leucine alone was able to restore muscle protein synthesis, a supplementation of this amino acid represents a good alternative to high-protein diets.

\section{References}

Anthony JC, Anthony TG, Kimball SR \& Jefferson LS (2001) Signaling pathways involved in translational control of protein synthesis in skeletal muscle by leucine. Journal of Nutrition 131, 856S-860S.

Anthony JC, Anthony TG, Kimball SR, Vary TC \& Jefferson LS $(2000 a)$ Orally administered leucine stimulates protein synthesis in skeletal muscle of postabsorptive rats in association with increased elF4F formation. Journal of Nutrition 130, 139-145.

Anthony JC, Yoshizawa F, Anthony TG, Vary TC, Jefferson LS \& Kimball SR (2000b) Leucine stimulates translation initiation in skeletal muscle of postabsorptive rats via a rapamycin-sensitive pathway. Journal of Nutrition 130, 2413-2419.

Arnal MA, Mosoni L, Boirie Y, Gachon P, Genest M, Bayle G, Grizard J, Arnal M, Antoine JM, Beaufrère B \& Patureau Mirand P (2000) Protein turnover modifications induced by the protein feeding pattern still persist after the end of dietary treatments. American Journal of Physiology 278, E902-E909.

Arnal MA, Mosoni L, Boirie Y, Houlier ML, Morin L, Verdier E, Ritz P, Antoine JM, Prugnaud J, Beaufrère B \& Patureau Mirand P (1999) Protein pulse feeding improves protein retention in elderly women. American Journal of Clinical Nutrition 69, 1202-1208.

Attaix D, Aurousseau E, Manghebati A \& Arnal M (1988) 
Contribution of liver, skin and skeletal muscle to whole-body protein synthesis in the young lamb. British Journal of Nutrition 60, 77-84.

Balage M, Sinaud S, Prod'homme M, Dardevet D, Vary TC, Kimball SR, Jefferson LS \& Grizard J (2001) Amino acids and insulin are both required for regulating assembly of the elF4EelF4G complex in rat skeletal muscle. American Journal of Physiology 281, E565-E574.

Balagopal P, Rooyackers OE, Adey DB, Ades PA \& Nair KS (1997) Effects of aging on in vivo synthesis of skeletal muscle myosin heavy-chain and sarcoplasmic protein in humans. American Journal of Physiology 273, E790-E800.

Barbosa-Tessmann IP, Chen C, Zhong C, Schuster SM, Nick HS \& Kilberg MS (1999) Activation of the unfolded protein response pathway induces human asparagine synthetase gene expression. Journal of Biological Chemistry 274, 31139-31144.

Barbosa-Tessmann IP, Chen C, Zhong C, Siu F, Schuster SM, Nick HS \& Kilberg MS (2000) Activation of the human asparagine synthetase gene by the amino acid response and the endoplasmic reticulum stress response pathways occurs by common genomic elements. Journal of Biological Chemistry 275, 26976-26985.

Bergström J, Furst P \& Vinnars E (1990) Effect of a test meal, without and with protein, on muscle and plasma free amino acids. Clinical Science 79, 331-337.

Berlanga JJ, Santoyo J \& De Haro C (1999) Characterization of a mammalian homolog of the GCN2 eukaryotic initiation factor 2 alpha kinase. European Journal of Biochemistry 265, 754-762.

Boirie Y, Gachon P \& Beaufrère B (1997) Splanchnic and wholebody leucine kinetics in young and elderly men. American Journal of Clinical Nutrition 65, 489-495.

Boirie Y, Gachon P, Corny S, Fauquant J, Maubois JL \& Beaufrère B (1996) Acute postprandial changes in leucine metabolism as assessed with an intrinsically labeled milk protein. American Journal of Physiology 271, E1083-E1091.

Bruhat A \& Fafournoux P (2001) Recent advances on molecular mechanisms involved in amino acid control of gene expression. Current Opinion in Clinical Nutrition and Metabolic Care 4, 439-443.

Bruhat A, Jousse C, Carraro V, Reimold A, Ferrara M \& Fafournoux P (2000) Amino acids control mammalian gene transcription: Activating transcription factor 2 is essential for the amino-acid responsiveness of the CHOP promoter. Molecular and Cellular Biology 20, 7192-7204.

Bruhat A, Jousse C, Wang XZ, Ron D, Ferrara M \& Fafournoux P (1997) Amino acid limitation induces expression of CHOP, a CCAAT/enhancer binding protein-related gene, at both transcriptional and post-transcriptional levels. Journal of Biological Chemistry 272, 17588-17593.

Buse MG, Jursinic S \& Reid SS (1975) Regulation of branchedchain amino acid oxidation in isolated muscles, nerves and aortas of rats. Biochemical Journal 148, 363-374.

Busquets S, Alvarez B, Llovera M, Agell N, Lopez-Soriano FJ \& Argiles JM (2000) Branched-chain amino acids inhibit proteolysis in rat skeletal muscle: Mechanisms involved. Journal of Cellular Physiology 184, 380-384.

Carlson BM (1992) Muscle regeneration and aging. In Keys for Regeneration, pp. 189-195 [CH Taban and B Boilly, editors]. Basel: Karger.

Cohn SH, Vartsky D, Yasumura S, Sawitsky A, Zanzi I, Waswani A \& Ellis KJ (1980) Compartmental body composition based on total-body nitrogen, potassium, and calcium. American Journal of Physiology 239, E524-E530.

Dardevet D, Sornet C, Attaix D, Baracos VE \& Grizard J (1994) Insulin-like Growth Factor-1 and insulin resistance in skeletal muscles of adult and old rats. Endocrinology 134, 1475-1484.

Dardevet D, Sornet C, Balage M \& Grizard J (2000) Stimulation of in vitro rat muscle protein synthesis by leucine decreases with age. Journal of Nutrition 130, 2630-2635.

Dardevet D, Sornet C, Bayle G, Prugnaud J, Pouyet C \& Grizard J (2002) Post-prandial stimulation of muscle protein synthesis in old rats was restored by a leucine supplemented meal. Journal of Nutrition 132, 95-100.

El Haj AJ, Lewis SE, Goldspink DF, Merry BJ \& Holehan AM (1986) The effect of chronic and acute dietary restriction on the growth and protein turnover of fast and slow types of rat skeletal muscle. Comparative Biochemistry and Physiology $85 \mathrm{~A}$, 281-287.

Elia M, Folmer P, Schlatmann A, Goren A \& Austin S (1989) Amino acid metabolism in muscle and in the whole body of man before and after ingestion of a single mixed meal. American Journal of Clinical Nutrition 49, 1203-1210.

Evans JL, Honer CM, Womelsdorf BE, Kaplan EL \& Bell PA (1995) The effects of wortmannin, a potent inhibitor of phosphatidyl-inositol 3-kinase, on insulin-stimulated glucose transport, GLUT4 translocation, antilipolysis, and DNA synthesis. Cellular Signalling 7, 365-376.

Fereday A, Gibson NR, Cox M, Pacy PJ \& Millward DJ (1998) Variation in the apparent sensitivity of the insulin-mediated inhibition of proteolysis to amino acid supply determines the efficiency of protein utilization. Clinical Science 95, 725-733.

Forbes GB \& Reina JC (1970) Adult lean body mass declines with age: some longitudinal observations. Metabolism 19, 653-663.

Frexes-Steed M, Warner ML, Bulus N, Flakoll P \& Abumrad NN (1990) Role of insulin and branched-chain amino acids in regulating protein metabolism during fasting. American Journal of Physiology 258, E907-E917.

Fulks R, Li JB \& Goldberg AL (1975) Effects of insulin, glucose and amino acids on protein turnover in rat diaphragm. Journal of Biological Chemistry 250, 290-298.

Funabiki R, Yagasaki K, Hara H, Nyumura N, Yoshizawa F \& Saito K (1992) In vivo effect of L-leucine administration on protein synthesis in mice. Journal of Nutritional Biochemistry 3, 401-407.

Garlick PJ, Fern M \& Preedy VR (1983) The effect of insulin infusion and food intake on muscle protein synthesis in postabsorptive rats. Biochemical Journal 210, 669-676.

Garlick PJ \& Grant I (1988) Amino acid infusion increases the sensitivity of muscle protein synthesis in vivo to insulin. Effect of branched-chain amino acids. Biochemical Journal 254, 579-584.

Harding HP, Novoa I, Zhang Y, Zeng H, Wek R, Schapira M \& Ron D (2000) Regulated translation initiation controls stressinduced gene expression in mammalian cells. Molecular and Cellular Biology 6, 1099-1108.

Hinnebusch AG (1994) Translational control of GCN4: an in vivo barometer of initiation-factor activity. Trends in Biochemical Science 19, 409-414.

Holloszy JO, Chen M, Cartee GD \& Young JC (1991) Skeletal muscle atrophy in old rats: differential changes in the three fiber types. Mechanisms of Ageing and Development 60, 199-213.

Holloszy JO, Smith EK, Vining M \& Adams SA (1985) Effect of voluntary exercise on longevity of rats. Journal of Applied Physiology 59, 826-831.

Kelly FJ \& Jefferson LS (1985) Control of peptide-chain initiation in rat skeletal muscle. Development of methods for preparation of native ribosomal subunits and analysis of the effect of insulin on formation of $40 \mathrm{~S}$ initiation complexes. Journal of Biological Chemistry 260, 6677-6683.

Kelly FJ, Lewis SEM, Anderson P \& Goldspink DF (1984) Preand postnatal growth and protein turnover in four muscles of the rat. Muscle and Nerve 7, 235-242.

Kimball SR, Jefferson LS, Fadden P, Haystead TAJ \& Lawrence JC (1996) Insulin and diabetes cause reciprocal changes in the 
association of eIF-4E and PHAS-I in rat skeletal muscle. American Journal of Physiology 270, C705-C709.

Kimball SR, Shantz LM, Horetsky RL \& Jefferson LS (1999) Leucine regulates translation of specific mRNAs in L6 myoblasts through mTOR-mediated changes in availability of eIF4E and phosphorylation of ribosomal protein S6. Journal of Biological Chemistry 274, 11647-11652.

Lewis SEM, Kelly FJ \& Goldspink DF (1984) Pre- and post-natal growth and protein turnover in smooth muscle, heart and slowand fast-twitch skeletal muscles of the rat. Biochemical Journal 217, 517-526.

Li JB \& Jefferson LS (1978) Influence of amino acid availability on protein turnover in perfused skeletal muscle. Biochimica et Biophysica Acta 544, 351-359.

Louard RJ, Barrett EJ \& Gelfand RA (1990) Effect of infused branched-chain amino acids on muscle and whole-body amino acid metabolism in man. Clinical Science 79, 457-466.

McNurlan M, Fern EB \& Garlick PJ (1982) Failure of leucine to stimulate protein synthesis in vivo. Biochemical Journal 204, 831-838.

Mays PK, McAnulty RJ \& Laurent GJ (1991) Age-related changes in rates of protein synthesis and degradation in rat tissues. Mechanisms of Ageing and Development 59, 229-241.

Millward DJ, Bowtell JL, Pacy P \& Rennie MJ (1994) Physical activity, protein metabolism and protein requirements. Proceedings of the Nutrition Society 53, 223-240.

Millward DJ, Fereday A, Gibson N \& Pacy PJ (1997) Aging, protein requirements, and protein turnover. American Journal of Clinical Nutrition 66, 774-786.

Millward DJ, Garlick PJ, Stewart RJ, Nnanyelugo DO \& Waterlow JC (1975) Skeletal-muscle growth and protein turnover. Biochemical Journal 150, 235-243.

Millward DJ, Odedra B \& Bates PC (1983) The role of insulin, corticosterone and other factors in the acute recovery of muscle protein synthesis on refeeding food-deprived rats. Biochemical Journal 216, 583-587.

Mordier S, Deval C, Béchet D, Tassa A \& Ferrara M (2000) Leucine limitation induces autophagy and activation of lysosome-dependent proteolysis in $\mathrm{C} 2 \mathrm{C} 12$ myotubes through a mammalian target of Rapamycin-independent signaling pathway. Journal of Biological Chemistry 275, 29900-29906.

Mosoni L, Houlier ML, Patureau Mirand P, Bayle G \& Grizard J (1993) Effect of amino acids alone or with insulin on muscle and liver protein synthesis in adult and old rats. American Journal of Physiology 264, E614-E620.

Mosoni L, Malmezat T, Valluy MC, Houlier ML, Attaix D \& Patureau Mirand P (1999) Lower recovery of muscle protein lost during starvation in old rats despite a stimulation of protein synthesis. American Journal of Physiology 277, E608-E616.

Mosoni L, Patureau Mirand P, Houlier ML \& Arnal M (1993) Age-related changes in protein synthesis measured in vivo in rat liver and gastrocnemius muscle. Mechanisms of Ageing and Development 68, 209-220.

Mosoni L, Valluy MC, Serrurier B, Prugnaud J, Obled C, Guezennec CY \& Patureau Mirand P (1995) Altered response of protein synthesis to nutritional state and endurance training in old rats. American Journal of Physiology 268, E328-E335.

Nair KS, Ford GC, Ekberg K, Fernqvist-Forbes E \& Wahren J (1995) Protein dynamics in whole body and in splanchnic and leg tissues in type I diabetic patients. Journal of Clinical Investigation 95, 2926-2937.

Nair KS, Matthews DE, Welle SL \& Braiman T (1992) Effect of leucine on amino acid and glucose metabolism in humans. Metabolism - Clinical and Experimental 41, 643-648.

Nair KS, Welle SL, Halliday D \& Campbell RG (1988) Effect of beta-hydroxybutyrate on whole-body leucine kinetics and fractional mixed skeletal muscle protein synthesis in humans. Journal of Clinical Investigation 82, 198-205.
Pacy PJ, Price GM, Halliday D, Quevedo MR \& Millward DJ (1994) Nitrogen homoeostasis in man - the diurnal responses of protein synthesis and degradation and amino acid oxidation to diets with increasing protein intakes. Clinical Science 86, 103-118.

Pain VM (1996) Initiation of protein synthesis in eukaryotic cells. European Journal of Biochemistry 236, 747-771.

Papet I, Glomot F, Grizard J \& Arnal M (1992) Leucine excess under conditions of low or compensated aminoacidemia does not change skeletal muscle and whole-body protein synthesis in suckling lambs during the postprandial period. Journal of Nutrition 122, 2307-2315.

Patti ME, Brambilla E, Luzi L, Landaker EJ \& Kahn CR (1998) Bidirectional modulation of insulin action by amino acids. Journal of Clinical Investigation 101, 1519-1529.

Preedy VR \& Garlick PJ (1986) The response of muscle protein synthesis to nutrient intake in postabsorptive rats: the role of insulin and amino acids. Bioscience Reports 6, 177-183.

Rennie MJ, Edwards RH, Halliday D, Matthews DE, Wolman SL \& Millward DJ (1982) Muscle protein synthesis measured by stable isotope techniques in man: the effects of feeding and fasting. Clinical Science 63, 519-523.

Rhoads RE (1999) Signal transduction pathways that regulate eukaryotic protein synthesis. Journal of Biological Chemistry 274, 30337-30340.

Rhoads RE, Joshibarve S \& Rinker-Schaeffer C (1993) Mechanism of action and regulation of protein synthesis initiation factor 4E: effects on mRNA discrimination, cellular growth rate, and oncogenesis. In Progress in Nucleic Acid Research and Molecular Biology, pp. 183-219 [WE Cohn and K Moldave, editors]. Academic Press.

Rooyackers OE, Adey DB, Ades PA \& Nair KS (1996) Effect of age on in vivo rates of mitochondrial protein synthesis in human skeletal muscle. Proceedings of the National Academy of Sciences USA 93, 15364-15369.

Rowe JW (1980) Aging and renal function. Annual Review of Gerontology and Geriatrics 1, 161-179.

Schneider EL \& Guralnik JM (1990) The aging of America. Impact on health care costs. Journal of the American Medical Association 263, 2335-2340.

Shah OJ, Anthony JC, Kimball SR \& Jefferson LS (2000) 4E-BP1 and S6K1: translational integration sites for nutritional and hormonal information in muscle. American Journal of Physiology 279, E715-E729.

Sinaud S, Balage M, Bayle G, Dardevet D, Vary TC, Kimball SR, Jefferson LS \& Grizard J (1999) Diazoxide-induced insulin deficiency greatly reduced muscle protein synthesis in rats: involvement of EIF4E. American Journal of Physiology 276, E50-E61.

Sood R, Porter AC, Olsen DA, Cavener DR \& Wek RC (2000) A mammalian homologue of GCN2 protein kinase important for translational control by phosphorylation of eukaryotic initiation factor-2alpha. Genetics 154, 787-801.

Svanberg E, Jefferson LS, Lundholm K \& Kimball SR (1997) Postprandial stimulation of muscle protein synthesis is independent of changes in insulin. American Journal of Physiology 272, E841-E847.

Svanberg E, Zachrisson H, Ohlsson C, Iresjö BM \& Lundholm KG (1996) Role of insulin and IGF-I in activation of muscle protein synthesis after oral feeding. American Journal of Physiology 270, E614-E620.

Taylor AW, Noble EG, Cunningham DA, Paterson DH \& Rechnitzer P (1992) Ageing, skeletal muscle contractile properties and enzyme activities with exercise. In Integration of Medical and Sports Sciences, pp. 109-125 [Y Sato, J Poortmans, I Hashimoto and Y Oshida, editors]. Basel: Karger. 
Volpi E, Lucidi P, Cruciani G, Monacchia F, Reboldi G, Brunetti P, Bolli GB \& De Feo P (1996) Contribution of amino acids and insulin to protein anabolism during meal absorption. Diabetes 45, 1245-1252.

Volpi E, Mittendorfer B, Rasmussen BB \& Wolfe RR (2000) The response of muscle protein anabolism to combined hyperaminoacidemia and glucose-induced hyperinsulinemia is impaired in the elderly. Journal of Clinical Endocrinology and Metabolism 85, 4481-4490.

Volpi E, Mittendorfer B, Wolf SE \& Wolfe RR (1999) Oral amino acids stimulate muscle protein anabolism in the elderly despite higher first-pass splanchnic extraction. American Journal of Physiology 277, E513-E520.

Volpi E \& Rasmussen BB (2000) Nutrition and muscle protein metabolism in the elderly. Diabetes Nutrition and Metabolism 13, 99-107.

Waterlow JC, Golden MH \& Garlick PJ (1978) Protein turnover in man measured with ${ }^{15} \mathrm{~N}$ : comparison of end products and dose regimes. American Journal of Physiology 235, E165-E174.

Welle S, Statt M, Barnard R \& Amatruda J (1994) Differential effect of insulin on whole-body proteolysis and glucose metabolism in normal-weight, obese, and reduced-obese women. Metabolism - Clinical and Experimental 43, 441-445.

Welle S, Thornton C, Jozefowicz R \& Statt M (1993) Myofibrillar protein synthesis in young and old men. American Journal of Physiology 264, E693-E698.

Yarasheski KE, Campbell JA, Smith K, Rennie MJ, Holloszy JO \& Bier DM (1992) Effect of growth hormone and resistance exercise on muscle growth in young men. American Journal of Physiology 262, E261-E267.
Yarasheski KE, Zachwieja JJ \& Bier DM (1993) Acute effects of resistance exercise on muscle protein synthesis rate in young and elderly men and women. American Journal of Physiology 265, E210-E214.

Yarasheski KE, Zachwieja JJ, Campbell JA \& Bier DM (1995) Effect of growth hormone and resistance exercise on muscle growth and strength in older men. American Journal of Physiology 268, E268-E276.

Yoshizawa F, Endo M, Ide H, Yagasaki K \& Funabiki R (1995) Translational regulation of protein synthesis in the liver and skeletal muscle of mice in response to refeeding. Journal of Nutritional Biochemistry 6, 130-136.

Yoshizawa F, Kimball SR \& Jefferson LS (1997a) Modulation of translation initiation in rat skeletal muscle and liver in response to food intake. Biochemical and Biophysical Research Communications 240, 825-831.

Yoshizawa F, Kimball SR, Vary TC \& Jefferson LS (1998) Effect of dietary protein on translation initiation in rat skeletal muscle and liver. American Journal of Physiology 275, E814-E820.

Yoshizawa F, Nagasawa T, Nishizawa N \& Funabiki R (1997b) Protein synthesis and degradation change rapidly in response to food intake in muscle of food-deprived mice. Journal of Nutrition 127, 1156-1159.

Young VR \& Munro HN (1978) N tau-methylhistidine (3-methylhistidine) and muscle protein turnover: an overview. Federation Proceedings 37, 2291-2300.

Young VR, Steffee WP, Pencharz PB, Winterer JC \& Scrimshaw NS (1975) Total human body synthesis in relation to protein requirements at various ages. Nature 253, 192-194. 